\title{
ChEMiCAlly FraCtionated FisSiON XENON IN SCANDinaVian ALUM SHale
}

\author{
A. MeshiK $^{1}$, N. H. Schovsbo ${ }^{2}$, And O. Pravdivtseva ${ }^{1}$
}

${ }^{1}$ Physics Department, Washington University, Saint Louis, MO 63130, USA,

${ }^{2}$ Geological Survey of Denmark and Greenland (GEUS),

Øster Voldgade 5-7, Dk-1350 Copenhagen K, Denmark.

The Scandinavian Alum Shale Formation was deposited in a large, shallow epicontinental sea that covered substantial part of paleocontinent Baltica. The shale is rich in amorphous organic matter (up to $25 \mathrm{wt}$ \% C) and in syngeneic trace elements, including U [1]. Shales are known to carry large quantities of $\mathrm{Xe}$ and $\mathrm{Kr}$ and were considered to be a potential sink for "missing" terrestrial Xe [2]. We have analyzed isotopic composition of Xe released from a particularly Urich part of the Alum Shale known as Kolm (U> 1\%) [1].

The Kolm shale exhibits two peaks of fission Xe release: minor at $450-850^{\circ} \mathrm{C}$ and major at $1000-1300^{\circ} \mathrm{C}$. The $\mathrm{Xe}$ isotopic composition of the major release is consistent with fission spectrum of ${ }^{238} \mathrm{U}$, while the composition of the minor peak is clearly anomalous: ${ }^{136} \mathrm{Xe} /{ }^{134} \mathrm{Xe} /{ }^{132} \mathrm{Xe} /{ }^{131} \mathrm{Xe} /{ }^{130} \mathrm{Xe} /$ ${ }^{129} \mathrm{Xe}=1 / 4.7 / 11.7 / 9.3 / 0 / 6.3$. This gigantic anomaly is most likely a result of Chemically Fractionation Fission (CFF) [3] characterized by preferential losses of heavy fission Xe isotopes which have relatively short-lived $\beta$-active precursors in fission chains: ${ }^{136} \mathrm{I}\left(\mathrm{T}_{1 / 2}=47 \mathrm{~s}\right)$ and ${ }^{134} \mathrm{I}\left(\mathrm{T}_{1 / 2}=3.7 \mathrm{~m}\right)$. This process results in apparent overabundances of Xe isotopes with more retentive precursors. Similar isotopic effect has been observed in $\mathrm{Xe}$ released at $\mathrm{T}<800^{\circ} \mathrm{C}$ from a volcanogenic U-ore etched with $6 \mathrm{M} \mathrm{HNO}_{3}$ [3].

Our observation confirms intense acid rock drainage and atmospheric weathering of $\mathrm{C}_{\mathrm{org}}$-rich alum shales sequence of the Cambrian-Devonian Baltoscandian Basin suggested by fractionation of $\mathrm{C}, \mathrm{N}$ and $\mathrm{S}$ isotopes [4]. Therefore $\mathrm{CFF}-\mathrm{Xe}$ can indicate the presence and extent of atmospheric weathering and possible leakage of uranium into the environment.

[1] Schovsbo (2002) GFF (Journal of the Geological Society of Sweden) 124: 107-116. [2] Podosek et al. (1981) Geochimica Cosmochimica Acta 45, 2401-2415. [3] Meshik et al. (2016) Physical Review C 93: 44614-1-9. [4] Fru et al. (2016) Applied Geochemistry 74, 94-108. 